\title{
慢性気管支炎に関する二，三の研究
}

\author{
*戸 塚 忠 政

\section{The Histological and Clinical Approaches to Chronic Bronchitis} \\ Tadamasa Tozuka, et al.
}

The 1st Department of Internal Medicine,

Shinshu University

We have made the histological studies on the comparisons of the autopsy cases of chronic bronchitis, the biopsy samples taken under bronchoscopy and the experimental bronchitis. In the preparation of the autopsy cases, hypertrophy as well as hyperplasia of mucous glands and the feature of bronchiolitis accompanied by the plasma cell infiltration were observed at any height of the bronchial tract. Around the mucous glands, the hyperplasia of the nerve fibres was also found by silver impregnation, which attached with the dilated blood vessels. From the histological view of the biopsy samples, we have classified the severity of chronic bronchitis into 3 grades. The close relationships were found between the histological graders and the bronchoscopic appearances as well as the course of the disease.

The histological appearances of the experimental bronchitis gave some resemblances with the biopsy and autopsy samples. From the study, it was suggested that some immunological factors were contributive to the pathogenesis of chronic bronchitis. By the immunofluorescent study of the biopsy samples, it was found that IgA immunoglobulin located abundantly in the plasma cells in the lamina propria. The abundant existence of $\operatorname{IgA}$ in the sputa of chronic bronchitis was also observed.

\section{序言}

慢性気管支炎（以下慢気）の研究は各方面か ら活発に行われているが, 尚幾多の問題が残さ れている, 本講演にあたつて先づ剖検例の検索 および気管支生検による組織像の臨床的意義に ついて検討すると共に, 本疾患の特徵をなす粘 液分泌過剩に関し, 気道壁神経系と粘液腺肥大 との関連を追究し, $\mathrm{SO}_{2}$ 吸入による動物実験を 行つた。更に慢気の病態生理に関し, 免疫学的 実験的研究を行い, 気道の組織学的変化から免

* 信州大学第一内科
疫学的要因を考察した。次に慢気および各種呼 吸器疾患の喀扊の蛋白分画について検索し, 生 検例での $\gamma$-A の局在についても考察した。

\section{I 病理組織学的研究}

\section{a ) 剖検例の検討}

症例「 1 三○昭○」38才 農夫, 咳嗽, 喀疢が 持続し再三肺炎症状を示し, 発病13年後に労作 時の息切れの増強をみ，入院した例で，頻脈， 呼吸困難, チアノ一ゼ，ばち状指が明瞭であり， 胸部に乾性，湿性亏音を聴取し，一秒率，\%VC の低下, 残気率の上昇を認めた。喀乲中に $\gamma$ 一 Streptococcus, Neisseria などの常在菌が主体 
を占め胸部レ線写真では両肺野に不規則小班状 影乃至網状影を認め, 下肺野に密度が高く, 上 肺野に一部線状影を認めた。嘫痰量は毎日 200 から $\mid 300 \mathrm{cc}$ の間を終始し, 微熱がみられ, 呼吸 困難は一時改善したものの, 再び起坐呼吸とな り, 死亡 2 日前より肺炎症状にて入院 2 ヶ月半 で死亡した。全経過は14年である。

剖検所見。気管, 気管支は一様に拡張がみら れ，悪区域気管支までおよんでいるが，特に中 心部に強い。内貯は膿性の粘液が多量にみら れ, 粘膜面は粗く, 凹凸に富み, 充血, 浮腫, 一部横皺を認める。肺門リンパ腺の腫脹が著し く, 心は肺性心の状態である。組織学的には気 道は亜区域気管支に至るまで粘液腺の肥大増生 がもつとも特徵的な所見であり, 更に上皮下に 形質球を主体とする細胞浸潤がみられ, 腺の間 質にまでおよぶ部分もみられる。気管支内腔の 分泌物による圧排のため軟骨と軟骨の間の粘膜 が著しい陥凹を示す部分もみられる。末稍気管 支では, 一部に細気管支炎の所見をみるが, 他の 部では細気管支拡張と滲出液の充満のみで炎症 所見はみられない。また一部の末㮐では不規則 な局所性肺気腫の所見を示し， Reid' ${ }^{1)}$ のいう 慢性気管支炎に基づく irregular emphysema の所見に一致する。左上葉気管支周囲には線維 化傾向の部分がみられ, その他喀痰の吸引によ ると思われる肺炎像を認める。

症例 2 百○み○子 72 才家婦 既往に慢性副 鼻腔炎があり，40才頃の発病で毎年悪化と軽快 をくり返し69才頃より息切れを覚え，翌年には 当科に入院したことがあり, 昭和 39 年には浮 腫, 呼吸困難の増強で12月再入院した。浮腫チ アノーゼの他に上肢のばち状指が著明であり胸 部に乾性ラ音をきき, 喀痰量は 1 日 $100 \mathrm{gr}$ 以上 を示し, Pseudomonas が途中から多数を占め, 血液ガスでは低 $\mathrm{O}_{2}$ 血症がみられ，心電図で肺 性心の所見を示す。胸部レ線写真では肺野全体 に小斑状乃至網状影を呈し，右下肺野は斑状影 が融合して濃厚影を呈している。経過は粘稠な 喀痰が 100ccを越え, 呼吸困難が強く, 強心剂, $\mathrm{O}_{2}$ 吸入などを併用し浮腫は軽快したが呼吸困 難が持続し, 翌年 7 月肺炎症状にて死亡した。 全経過35年。剖検所見。左右主気管支共著明
な縌鲔を形成し，右 $\mathrm{B}_{7}$ は軽度に搪張した状 態で末稍まで続き，垔区域まで縦蛝が明瞭であ る。右中葉は退縮し, 上葉肺尖部は気腫状で 葉は肺炎病单または蜂窩状の部分を認める。左 下葉に出血巣をみる。リンパ腺は肺門部, 分岐 部に多数柔く腫脹している。組織学的には一般 に気管支上皮の脱落が著しく, 粘液腺肥大, 導 管拡張, 粘膜下血管増生および拡張が著明であ る。縦皺形成の原因として平滑筋肥大の他に弹 性線維増生の関与む考えられる。更にこの例で 特徵的なのは細気管支の变化であり, 壁全体に 形質球を混える細胞浸潤が強く, 沉細気管支炎 の像がびまん性にみられ，また部位によつては 形質球を含む肉芽組織により閉塞された像即ち 閉塞性細気管支炎がみられる。その他中等大の 気管支壁にも肉芽による突出を示し, 気道壁の 変化の強いことがうかがわれる。この例は山中 氏等のいうびまん性沉細気管支炎の範ちゆうに 入るものと考えられる。以上二例共その終末像 として共通していることは, 気道粘液腺の著し い肥大または増生であり, 二症例の主気管支に

図 1

\section{各剖検例の右主気管支粘液腺 肥大傾向(Reid's Index) $と$ 年令分布}

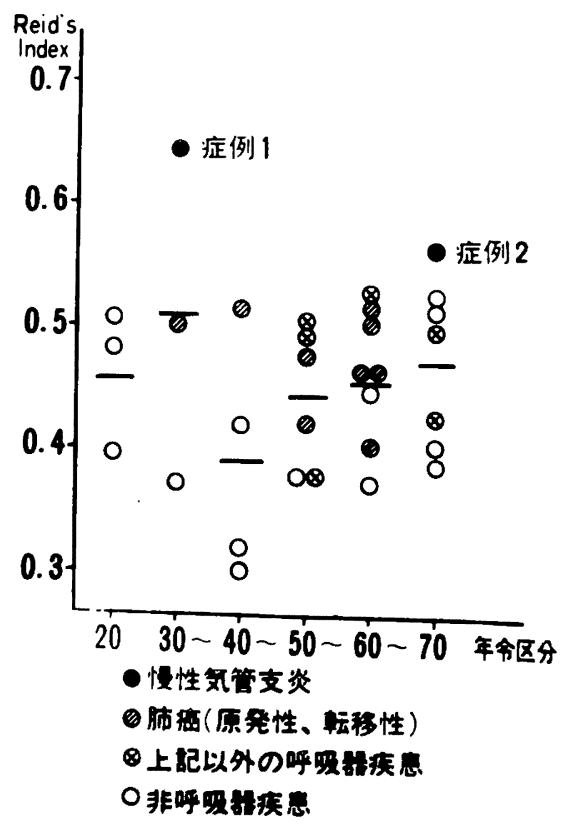


おける Reid's index がよくそれを示している （図 1)。リンパ腺は二例共腫脹が著しく，炎症 性変化として感染が強調さるべきであり，更に 両者共, 形質球を主体とする細胞浸潤が強く, 症例 2 はびまん性沉細気管支炎の像を呈し, 症 例 1 は細気管支炎に線維化の進展，不規則な局 所的肺気腫の合併など，気管支炎の進展に部位 的, 質的に種々の変化が加味されるものと考え られる。

慢気の電子顕微鏡的所見に関し，多くの知見 が得られているが，それらのうち基底膜の所見 については, 肥厚および厚さの不規則性が著明 で half-desmosome の増加がみられ, 光顕レベ ルでの基底層内にはコラゲンの増加が著明であ り，時に幼若な弾性線維もみられた。

b ）気管支生検による組織像と臨床病理学的 検討

所謂 Fletcher の診断基準にほぼ該当する62 例の慢気の主気管支生検を行い，その病理組織 像を次の三型に分類した。I 型：気管支上皮に 主に病変を認め, 杯細胞の増生, 粘膜下組織の 浮腫, 充血, 軽度の細胞浸潤を認めるもの。II 型：I 型の上皮性変化の増強に加え, 基底層の 肥厚, 粘膜下の強、細胞浸潤に加え粘液腺の肥 大, 増生の著明なもの。林型：上皮は萎縮し, 基底層の肥厚, 蛇行, 粘膜下 組 織の 結合織増 生，それに基づく腺の不整形増生を示すものと した（分類にさいし移行型に属する例は結合織 増生, 腺の変型などを参考にした)。䍜病期間と の関係をみると表 1 の如く I 型は 3 年未満が半

\section{表 1}

罹病期間と病理 型

\begin{tabular}{c|c|c|c}
\hline 痽病期間 & 3 年未満 & $3 \sim 7$ 年 & 8 年以上 \\
\hline 病理型 & 5 & 3 & 0 \\
I & 8 & 17 & 9 \\
III & 2 & 5 & 13 \\
\hline 計 & 15 & 25 & 22 \\
\hline
\end{tabular}

数以上を占め, 8 年以上はなく, II 型は $3 \sim 7$ 年がもつとも多く, III型は 8 年以上が半数以上 で, 3 年末满が 2 例に過ぎない。以上 I 型は罹 病期間の短いものが多く，III型は長いものが多
く，II型はその中間に位し，署病期間と組織病 型の間に関連を認める。息切れのあるものは62 例中約半数の32例で病型別にみると I 型で少な く III型で多い。気管支鏡所見を萎縮を始め四っ の所見群にわけて病型別にみると, 萎縮を認め る所見は I 型に無く，而型に多く，また変化な しの所見は而型に無く，気管支鏡的所見と病型 との間に関連が認められた。

\section{II 粘液分泌に関する研究}

a ）気道壁の神経節細胞および神経線維

気道壁の平滑笳, 血管, 腺を支配する自律神 経節は軟骨外および軟骨内にみられ, 時に粘液 腺の腺房間または腺に接して認められ，更に神 経線維が腺房をとり囲むようにして認められる 場合がある。慢気例では肥大した粘液腺の周囲 に多くの神経節細胞がみられ，中には萎縮した 神経節細胞とその周囲の Gliose の所見が認め られる。腺内の神経線維の増生は極めて著しく ，不規則に肥厚した線維の混在を認め, これら は同じ腺内の挔張した血管壁と密接な関連を有 し，粘液腺の機能に対する血管と自律神経の関 与がうかがわれる。

b ) $\mathrm{SO}_{2}$ 吸入による実験的研究

ウィスター系ラットを用い, Gas chamber内 $\mathrm{SO}_{2}$ 吸入による実験的研究を行つた。 $\mathrm{SO}_{2}$ 濃 度は初めの 2 週は 200 400p.p.m. で，以後は 400p.p.m. とし, 曝露期間により三群に分け, 各気道部位の肉眼的粘液の有無および組織学的 観察を行つた。粘液は対照では13例中11例に陰 性であり, 曝露群に全例陽性を示し, 区域気管 支以下に多くみられる傾向を認めた。組織学的 に気管における杯細胞数は対照群と曝露群との 間に有意の差なく，主気管支における杯細胞数 は両群との間に有意差を示し（5\%の危険率） 更に直径 $500 \mu$ 以下の細気管支の杯細胞数は対 照群では極めて少ないのに対し, 曝露群で多数 増生して著明な差異を示し, 細気管支側に変化 の強いことを示している。長期曝露群の主気管 支上皮に乳嘴状増生と扁平上皮化生を示すむの がみられる。 


\section{III 病態生理に関する研究}

a ) 気管気管支粘膜遷延感作による実験的研究 気道粘膜の抗原性が各研究者により報告され ているが， ${ }^{2(3(+) 5)}$ 気道粘膜の慢性炎症にさい し，免疫学的な要素の関与を知る目的で，まゔ hetero の動物間にcrudeな気管・気管支粘膜を用 いて遷延感作を行い組織学的検索と皮虞反応を 行つた。実験には家鬼の気管・気管支粘膜を剥離 し, 生食で洗滌後, Emulsion をつくり Freund's incomplete adjuvant を混じてモルモットに感 作し, 短期 ( 1 週 1 回で 4 回), 長期（10 25回 までのもの）および対照群について比較した。 気管基底層の肥厚およびその不規則性が感作の 長期になる程著明となり, 上皮下組織の線維化 が長期感作群の一部の例に軽度に認められた。 長期感作群では気管基底層の著しい不規則な肥 厚を示すと共に, 基底層内に毛細血管の侵入を 認めた。皮膚反応については抗原として気道粘 膜 Emulsionの他に対照として腎その他を用い た。12時間後の判定で両感作群共陽性反応が明 瞭であり，ことに長期感作群に強い反応を示す ものが多くみられた。尚腎抗原でも同様の交叉 反応を認めた。家鬼で行つた passive cutaneous anaphylaxis 反応は陽性であつた。以上気道粘 膜の遷延感作により抗体の産生が推定されると 共に気管基底層の変化は臨床的に経過の長い慢 気にみられる気管支基底層の肥厚の事実と関連 して興味ある知見と考えられる。

b ）感作家鬼における抗気管・気管支粘膜血 清に対する気道の組織学的変化

前記と同様 hetero の動物間で作つた抗気道 粘膜抗体を, 粘膜を提供したもとの動物にかえ すことにより気道粘膜の組織学的変化を追究し た。実験には家鬼の気管・気管支粘膜 Emulsion を山羊に静注し。抗体価（補体結合反応）の上 昇を確め, DEAE Cellulose Collum Chromat ography にて抗体価の高い分画を用いた。実験 家鬼群は正常山羊血清で感作後, 週 3 回, 10週 にわたり, 分画単独静注群, $\mathrm{SO}_{2}$ 吸入併用群に 静注し, 対照には正常山羊血清の対応分画の静 注を行つた。気管についての成績は粘膜固有層 では対照, $\mathrm{SO}_{2}^{\prime}$ 単独吸入, および無処置群にく
らべ，静注群および静注 $+\mathrm{SO}_{2}$ 吸入併用群は， 線維素染色陽性の細線維の増生がみられた。同 部の弾性線維は増生の部位もみられるが喍銀線 維の増生はみられない。これら抗原抗体反応に よる細線維の形成は自己抗体の形態学的面での 病変について示唆を与えるものと考えられる。

c）喀痰の蛋白分画について

慢気および各種呼吸器疾患における気管・気 管支分泌物扔よび喀痰の蛋白分画を寒天ゲル内 電気泳動法, 免疫電気泳動法により検索し,さ らに一元平板免疫拡散法により定量を行いそ の結果, 気道分泌物および喀痰中の分画にはア ルブミン, トランスフェリン, $\gamma-\mathrm{A}, \gamma-\mathrm{M}, \gamma-\mathrm{G}$ などが主であることが認められた。これらの量 的関係から気管気管支分泌物および喀痰の蛋白 分画パターンを $\mathrm{O}$ 型から V 型までの 6 型に分類 $し,{ }^{6)}$ 各種呼吸器疾患別出現頻度を検討した。 慢気ではIII型即ちアルブミンが少量認められ， slow moving の $\gamma-$ グロブリンが中等度に認 られるもの即ち Biserte 等" ${ }^{7}$ の分類の Allergic asthma type のものがもつとも多く，28例中 64.3\%に認められた（図2）。慢気の而型にみら

図 2
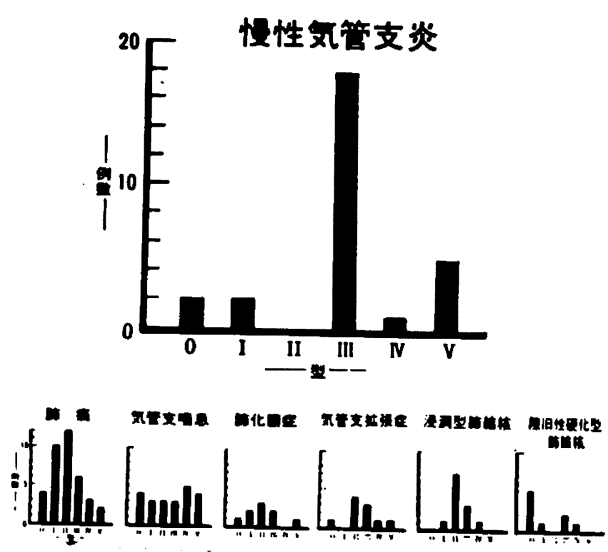

れる slow-moving のグロブリンは $\gamma$-A が主体 であることが免疫電気泳動法で確認されたので 各蛋白の分画の定量を一元平板免疫拡散法で行 つた。その結果, 慢気では $\gamma$-A の喀凖中の源 度は平均 $74.8 \mathrm{mg} / \mathrm{dl}$ と高く, 喀痖中の総蛋白 量中に占める割合は $40.1 \%$ にも及び，この值は 他の呼吸器疾患における值に比し, 著明に増加 
している点が注目される(図 3 )。これは唾液，

図 3

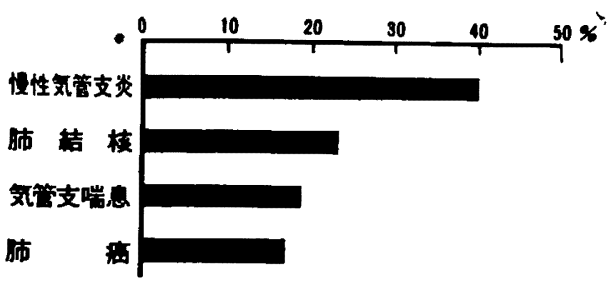

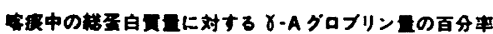

音汁と共に分必液中の抗体が主に $\gamma$-A であると する見解を裏ゔける所見である。

d) $7 \mathrm{~S} \gamma$-A， $\gamma$-G 抗血清による気道壁の免疫 組織学的変化

最近粘膜局所の防徱機構として分必型 $\gamma$-Aの 既念が強調されるようになつた。Tomasi 等 ${ }^{8)}$ こよれば分必型 $\gamma$-A は粘膜上皮細胞で産生さ れる一種の煻蛋白と 7S $\gamma$-A が結合したものと 考えられ，これが粘膜表面を保護するとされる j゙，その分泌液中の $\gamma$-A は血清 $\gamma$-A でなく粘 莫固有層の形質球から産生され直接粘膜側に分 必されるといわれている。教室の各症例につ き, 血清 $\gamma$-A， $\gamma-\mathrm{G}$ などの抗血清を用い，螢光 克体法直接法で検索した結果, 生検気管支の粘 谟固有層の形質球様の細胞螢光は 3 I例中半数以 上の19例にみられず，またみられた例でも数は 少なく，生検材料という制限はあるにしても [ourville ${ }^{9)}$ のいう如く気道壁形質球は腸管など こ比し，一般には数が少ないと考えられる。し jし, 気道感染群 (慢性気管支炎, 気管支拡張 芷を含む）と肺癌その他（肺結核を含む）の二 羊に分けて観察すると感染群 8 例中固有層の細 包螢光陽性例は 5 例で, 肺癌その他の群 23 例中 i7 例の陽性にくらべて明らかに多く，この点で 感染と形質球の関連がうかがわれる。基底層 刀 $r$-A については，その外層部または内層部 こ顆粒状または断裂した線状にみられ，時に層 全体にみられるかまたは散在性に認められる。 気管支喘息例では肥厚した基底層の内層, 外層 こやや太、線状の螢光が広範囲に認められる場 合がある。上皮に関しては一般に $\gamma-\mathrm{G}$ では基 底層を境にして螢光が上皮側には殆どみられな 例が多く, 同一標本で $\gamma$-A では基底層を境
にして上皮側に螢光がみられ固有層には細胞螢 光を除いては極めて弱くこのように $\gamma$-A と $\gamma$-G の螢光のパターンが基底層を境にして異る場合 のあることは，分必型 $\gamma$-A が粘膜上皮に関与 する興味ある所見と思われる。症例の一部につ いて組織 $\gamma$-A と血清 $\gamma$-A 值との比較を行つた が，血清 $\gamma$-A が高值を示すものでも上皮およ び固有層の螢光は必らずしも増強せず，両者間 に平行関係が認められるとは限らないことが判 明した。

\section{結語}

1）慢性気管支炎の病理組織像は各気管支レベ ルにおける粘膜腺の肥大増生であり，一部には 細気管支炎の存在, 線維化の進展, 肺気腫の合 併などがみられる。

2）肥大した粘液腺の周囲には変化した神経節 細胞や神経線維が多くみられ，これらは同じ腺 内の拡張した血管壁と密接な関連を有し, 粘液 腺の機能に対する血管と自律神経の関与がうか がわれる。

3）気管支生検による組織像の病型分類は慢性 気管支炎の罹病期間，気管支鏡所見等々密接な 関係を有している。

4）気管・気管支粘膜遷延感作実験により抗体 の産生が推定される成績を得, また気管基底層 の肥厚を認めた。

5）感作家鬼における抗気管・気管支粘膜血清 に対する気道の組織学的変化を追究して, 粘膜 固有層の細線維の増生を認めた。

6）喀痰の蛋白分画を検索し，慢性気管支炎で は slow moving $\gamma$-グロブリンが中等度に認め られ，この主体が $\gamma$-A であることを確認した。 更に喀痰中 $\gamma$-A の濃度を一元平板免疫拡散法 にて定量し，高值であることを認め, 喀痰中の 総蛋白量中に占める割合も他の呼吸器疾患に比 し，明らかに増加していた。

7）螢光抗体法による生検気管支の粘膜固有層 の $\gamma$-A による形質球様細胞螢光は気道感染群 に認められる例が多かつた。

8）血清 $\gamma$-A の定量成績と生検、気管枝組織の $\gamma$-A 螢光の程度の間には, 検索し得た範囲では 平行関倸が認められなかつた。 
気食会報 -21 巻

協同研究者 草間昌三, 半田健次郎, 望月一郎 花里重利, 清水 浩安, 藤本宗行 百瀬邦夫, 清水 啓介, 中野晃明 小林俊夫, 中沢 武夫, 相馬昭彦 佐藤 忍, 藤森 勲, 伊藤公夫 立岩孝之

1) Reid L.: The Pathology of Emphysema Lloyd-Luke Ltd, 1967.

2) Suhs R.H.: Amer. Rev. Resp. D. 91: 64, 1965

3) Suhs R.H. et al: Amer. Rev. Resp. D., 91:59,

1965.

4) Rose N.R.: J. Immunol., 94: 741, 1965.

5) Wagner V.: Acta allergol., 20: 1, 1965.

6) 藤本宗行 : 信州医誌 17, 593, 1968

7) Biserte G.R. et al.: Exposes Ann. Biochem. Med., 24: 85, 1963.

8) Tomasi, T.B. et al.: J. Exp. Med., 121: 101, 1965.

9) Tourville D.R.: J. Exp. Med., 129: 411, 1969

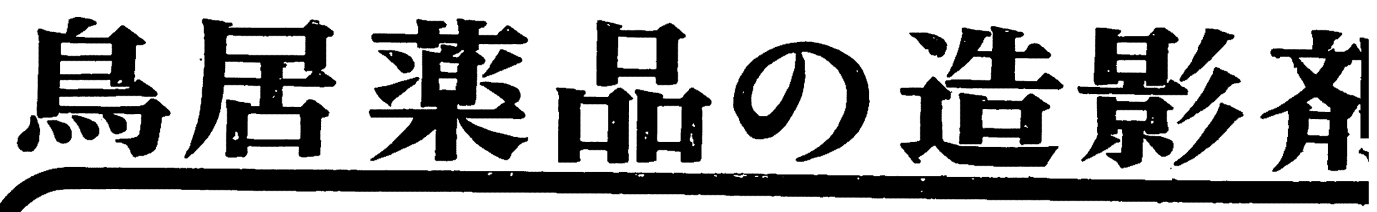

for Bronchography

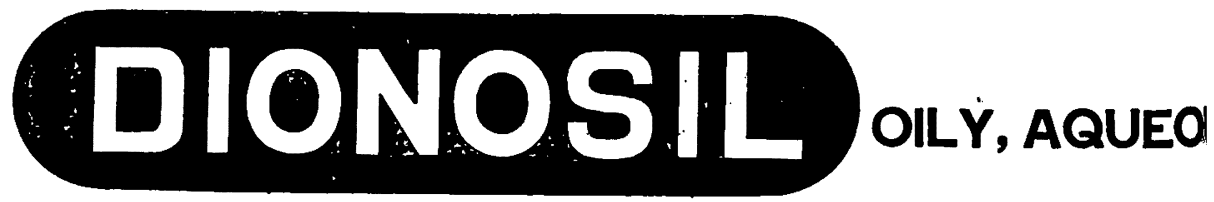

特長 1. 影像きわめて鮮明

2. 吸収よく24時間後にはほとんど消失する

3. 操作技術が容易で刺激副作用を認めない

4. ベイアル瓶入のため必要量だけ使用でき経済的である

包装油性・水注 $15 \mathrm{ml} 60 \mathrm{ml}$ バイアル入 